\title{
DISTRIBUTION OF AFLATOXIN CONTAMINATION IN MAIZE SAMPLES ${ }^{1}$
}

\author{
Eduardo Micotti da GLORIA,*, César Francisco CIACCO ${ }^{3}$, José Francisco LOPES FILHO ${ }^{4}$, \\ Cynthia ERICSSON 5 , Silvio Sandoval ZOCCHI ${ }^{2}$
}

\section{SUMMARY}

The distribution of the aflatoxin contamination was studied among four maize fractions, separated according to Brazilian grading rules for maize. The fraction that contained fermented, moldy, heated and sprouted grains normally had the highest levels of aflatoxin. However, the fraction contribution to the whole sample contamination level took into account the contamination fraction level and its weight to the whole sample. Considering this, the fraction that contained insect damaged, hollow, up to $1 / 4$ fermented and grains damaged by other causes was normally the fraction responsible for the total contamination level in the samples. Nevertheless, the fraction contributions were variable from sample to sample. Therefore, in conclusion, it was not possible to establish a standard behavior for grain fraction-type contribution for different maize lots. The Brazilian grading by qualitative types applied to samples did not show statistic correlation with aflatoxin contamination levels $(\mathrm{P}<0.05)$. Two type- 1 samples (the best quality type) presented contamination of 380 and $146 \mathrm{ng} / \mathrm{g}$. The number of samples with contamination levels above those allowed by Brazilian law (20ng/g) was the same for qualitative types 2, 3, and BS (Below Standard).

Keywords: aflatoxin; contamination; distribution; grain type; maize.

\section{RESUMO}

DISTRIBUIÇÃO DA CONTAMINAÇÃO COM AFLATOXINAS EM AMOSTRAS DE MILHO. A distribuição da contaminação com aflatoxinas foi estudada entre quatro frações separadas de acordo com as regras brasileiras de classificação do milho. A fração que continha grãos ardidos, mofados, queimados e brotados normalmente tinha os níveis mais altos de aflatoxina. Contudo, a contribuição da fração para a contaminação da amostra inteira levou em conta o nível de contaminação da fração e seu peso na amostra inteira. Considerando isto, a fração que continha os grãos danificados por insetos, chochos, fermentados até $1 / 4$ e injuriados por outras causas, foi normalmente a maior responsável pelo nível de contaminação total das amostras. Apesar disto, as contribuições das frações foram variáveis de amostra para amostra. Portanto, foi concluído que não foi possível estabelecer um comportamento padrão para contribuição das frações de grãos para diferentes lotes de milho. A classificação brasileira por tipos aplicada nas amostras não mostrou correlação estatística com os niveis de contaminação com aflatoxinas $(\mathrm{P}<0,05)$. Duas amostras classificadas com o melhor tipo qualitativo (tipo 1) apresentaram contaminação de 380 e 146ng/g. O número de amostras com nível de contaminação acima daquele permitido pela lei brasileira (20ng/g) foi o mesmo para os tipos qualitativos 2, 3 e AP (Abaixo do Padrão)

Palavras-chave: aflatoxina; contaminação; distribuição; tipo de grão; milho.

\section{1 - INTRODUCTION}

The aflatoxin contamination in Brazilian maize was previously reported by FONSECA et al. [4, 5], SOARES \& RODRIGUEZ-AMAYA [14], and GLORIA [6]. While official rules for qualitatively characterizing maize lots have been used in Brazil since 1976 [2], there is no information in the literature about the distribution of aflatoxin contamination among different samples fractions considered in Brazilian maize grading rules. Despite this, it is common for Brazilian maize users to consider, for any maize lot, specific maize fractions considered in the rules, such as fermented and sprouted grains, foreign materials as well as broken grains and impurities as the major source responsible for detected aflatoxin levels.

The literature documents that the distribution of aflatoxin contamination on agricultural products, including maize, is extremely heterogeneous $[7,8,12]$.

\footnotetext{
${ }^{1}$ Recebido para publicação em 25/09/2003. Aceito para publicação em 14/11/2003 (000986).

2. Universidade de São Paulo-ESALQ, CEP-13418-900, Piracicaba-SP. Brasil. Fax: (55) (19) 422-5678. E-mail: emgloria@carpa.ciagri.usp.br

3. Universidade Estadual de Campinas - FEA, Campinas-SP. Brasil.

4. Universidade Paulista-IBILCE, São José do Rio Preto-SP, Brasil.

5. Vega Armazéns Gerais, Mogi-Guaçu-SP, Brasil.

*A quem a correspondência deve ser enviada.
}

Studies conducted by SHOTWELL, GOULDEN \& HESSELTINE [10, 11] on the distribution of aflatoxin contamination among maize fractions showed that the distribution was variable for each maize lot and there was no assurance that high contamination levels were due to the amount of a specific maize fraction present in the lot.

The main objective of this work was to study the distribution of aflatoxin contamination among maize fractions separated from samples according to the grain fraction defined by the official Brazilian maize grading rules. The contribution of each fraction to the total aflatoxin contamination level in the maize samples was also evaluated.

\section{2 - MATERIAL AND METHODS}

\section{1 - Samples}

The samples for this study were chosen from those collected on a routine basis by the raw material quality control service of the Brazilian maize processing industry. From samples collected over the study period, 22 samples were employed for the tests. According to the industry quality control, 19 samples were classified as contaminated.

The determination and separation of contaminated and non-contaminated samples were done initially by 
industrial sources with the fluorescence BGY (Bright Greenish Yellow) test. These tests were confirmed by a rapid immunoaffinity column tests (Aflatest, Vicam, Watertown, MA, USA).

Samples were collected from arriving trucks at different load points with an automatic sampler. A variable number of sub-samples were collected according to the total load weight. The sub-samples were mixed to obtain a representative sample (2.9 to $5.0 \mathrm{~kg})$. After sampling, the moisture content was determined with a Motonco moisture tester (Motonco 919E, Motonco, Patherson, NJ, USA). Samples with moisture content higher than $14.5 \%(\mathrm{wb})$ were stored for about 4 days in a freezer $\left(-12^{\circ} \mathrm{C}\right)$ to minimize fungal activity until the samples could be classified, fractions separated and transported to the laboratory.

\section{2 - Separation of fractions}

The collected samples had their grains graded by industrial classifiers and separated into the following fractions: fraction 1 - with fermented, sprouted, moldy, and heated grains; fraction 2 - with damaged grains (insect damaged grains, hollow, up to $1 / 4$ fermented, broken and damaged by other causes); fraction 3 - with regular grains; fraction 4 - with impurities, foreign materials and other fragments. The maize grain fractions listed above were based upon established Brazilian maize grading standards. The grain types considered in each fraction of this study were: Fermented - grains or pieces of grains that show discoloration by heat and humidity or fermentation in more than $1 / 4$ of the grains (it considered all of the germ extension and any other parts of the grain). Sprouted - grains or pieces of grains that show visible germination. Moldy - grains or pieces that are partially or completely covered with fungal growth, which is visible to the naked eyes. Heated grains showing color modification, which is typical of high temperatures caused by excessive drying. Due to the visible similarity with fermented grains, these two types of grains were grouped together. Damaged grains broken (pieces of grains that do not pass through a $5.0 \mathrm{~mm}$ round-holed sieve), hollow (undeveloped grains), attacked by insects, rodent or parasites, fermented up to $1 / 4$ of the grains, and damaged by other causes. Impurities, fragments and foreign materials - impurities and fragments of the maize plant as well as grains or grain pieces that pass through $5.0-\mathrm{mm}$ round-holed sieves. Foreign material is considered as any other grains or seeds, vegetative residues and foreign bodies of any nature other than from the maize plant.

After separation, the fractions from each sample were identified, weighed, prepared for aflatoxin analysis and stored at $-18^{\circ} \mathrm{C}$ to avoid any additional fungal activity prior to aflatoxin analysis.

\section{3 - Sample preparation for aflatoxin analysis}

The fractions were ground down to a granulometric 20-mesh size. For fraction 3, normal grain, the weights were normally higher than $1,500 \mathrm{~g}$, therefore, a sub- sample was taken before grinding to obtain an amount of ground grain similar to that of the other fractions analyzed. In this case, the sub-samples were taken by a sub-sampler mill (RAS Mill, Romer Labs, Inc., Union, MO, USA), which collected $10 \%$ of the material.

\section{4 - Aflatoxin analyses}

Aflatoxin extraction was conducted according to SOARES \& RODRIGUEZ-AMAYA [14] method using a 5 g-analytical sample. When the amount of the material of a specific fraction was less than $100 \mathrm{~g}, 25 \mathrm{~g}$-analytical samples were used in order to run duplicate analyses. The presence of aflatoxin was checked by two-direcional thin layer chromatography (TLC) using $10 \times 10 \mathrm{~cm}$ plates cut from $20 \times 20 \mathrm{~cm}$ aluminum chromatoplates covered with silica gel 60 (Art. 1.05553, Merck, Merck KGaA, Darmastadt, Germany).

The development of chromatography plates was done by a two-step dimensional method where the first separation step used a solvent solution of chloroform and acetone (9:1). After separation, the plates were airdried for 20min. For the second dimension, the separation was done by rotating the plates $90^{\circ}$ followed by placing them into a solvent solution composed of toluene, ethyl acetate, formic acid and chloroform (5:4:1:4). The aflatoxin standard solutions had the following concentrations: $\mathrm{B}_{1}=0.1740 \mu \mathrm{g} / \mathrm{mL} ; \mathrm{B}_{2}=$ $0.1064 \mu \mathrm{g} / \mathrm{mL} ; \mathrm{G}_{1}=0.1677 \mu \mathrm{g} / \mathrm{mL}$ and $\mathrm{G}_{2}=0.1047 \mu \mathrm{g} / \mathrm{mL}$. These solutions were prepared from Sigma standards (Sigma AF -1, Sigma-Aldrich Co., St. Louis, MO, USA) and the concentrations were checked by the methodology 971.22 of the ASSOCIATION OF THE OFFICIAL ANALYTICAL CHEMISTS [1].

The aflatoxin was quantified by comparing the aflatoxin spot intensities in the samples against the aflatoxin standard spots developed in the toluene/ethyl acetate/formic acid/chloroform solvent. Aflatoxin contamination results presented are the mean values of duplicate analyses considering the sum of the contamination of aflatoxins B1, B2, G1, and G2. The maximum variation between duplicate results accepted was $30 \%$. Otherwise, the analyses were repeated. The identity of aflatoxins $\mathrm{B} 1$ and $\mathrm{G} 1$ were checked by the methodology 985.17 of AOAC [1]. The method showed recovery levels of $88 \%, 85 \%, 83 \%$, and $82 \%$ for aflatoxins $\mathrm{B}_{1}, \mathrm{~B}_{2}, \mathrm{G}_{1}$ and $\mathrm{G}_{2}$, respectively for artificial contamination levels of 0.6 to $3.2 \mathrm{ng} / \mathrm{g}$. The detection limits were 0.3 , $0.2,0.2$ and $0.1 \mathrm{ng} / \mathrm{g}$ for aflatoxins $\mathrm{B}_{1}, \mathrm{~B}_{2}, \mathrm{G}_{1}$ and $\mathrm{G}_{2}$, respectively. The quantification limit adopted for each aflatoxin was $\operatorname{lng} / \mathrm{g}$.

\section{5 - Statistical analysis}

The correlation between fraction levels in the sample and total aflatoxin contamination levels was analyzed for significant probabilities at $\mathrm{P} \leq 0.05$ according to SOARES, FARIAS \& CESAR [13].

The fraction contributions to the total sample aflatoxin contamination levels were studied by percentile analysis. In this case, the software EXCEL was used. 


\section{3 - RESULTS AND DISCUSSION}

Among the 22 samples evaluated, 20 presented a detectable level of contamination. One sample that was not considered contaminated by industrial evaluation procedures showed low levels of aflatoxin when the fractions were analyzed in the laboratory (Table 1).

The variation in the contamination levels observed between the results from immunoaffinity and TLC for the whole sample, as seen in Table 1, was probably due to differences found in contamination homogeneity of the sampled materials. Analytical samples analyzed by immunoaffinity were collected from samples of intact whole grain, therefore, with heterogeneous distribution of aflatoxin contamination. TLC results were from whole sample estimates taking into account the weight and contamination level of each sample fraction. In fraction analysis, the analytical samples were gathered after grinding, therefore, from sample material that had better distribution of aflatoxin contamination.

The contamination levels observed in fraction 1 were, generally, higher than those from other fractions. However, in seven samples, the fraction 2 or 4 presented the highest levels. This shows that, contrary to the belief of Brazilian maize users, the highest contamination levels are not exclusively related to grain showing fungal activity such as in fraction 1 (Table 2).

The contribution of each fraction to the total sample contamination level, as seen in Table 2, was calculated based upon the concentration of aflatoxin and the relative weight of the fraction in respect to the total sample weight. Total sample contamination was estimated by dividing the fraction contribution sum (considering the weight and the fraction contamination level) by the total sample weight.

The fraction contributions were analyzed by percentile (Table 3) that graded samples according to the contamination level. Percentile analysis show in the first quartile $(25 \%$ of samples that showed lower contamination levels), median (50\% of samples), third quartile $(75 \%$ of samples that showed lower contamination levels and interquartile range samples that showed contamination level between first and third quartile) that fraction 2 was normally the major responsible $(21.1,43.9,58.8$ and 37.8 , respectively) for the total sample contaminations. However for some samples, fractions 1, 3 and 4 were the main contributors to the total sample contamination as showed at Table 2 and Figure 1.

The apparent contradiction between data of higher contamination levels observed for material from fraction 1 and data for the highest contribution observed for fraction 2, can be explained by the relationship between the relative amounts of these fractions in the samples and their levels of contamination. Although grains from fraction 1 showed higher aflatoxin levels, they were present at a lower percentage (0.6 to 6.4\%) in the sample; therefore, they contributed less to the total than fraction 2 . The fraction 2 normally showed lower contamination levels than fraction 1 , but it was present in a higher percentage $(7.1$ to $30.2 \%)$ relative to the total sample's weight, therefore, providing most of the aflatoxin estimated for the sample.

TABLE 1. Qualitative characteristics shown by the studied samples.

\begin{tabular}{|c|c|c|c|c|}
\hline \multirow[t]{2}{*}{ Sample } & \multirow[t]{2}{*}{$\begin{array}{c}\text { Mo isture } \\
\%\end{array}$} & \multirow[t]{2}{*}{$\begin{array}{c}\text { Qualitative } \\
\text { Type }^{\text {a }}\end{array}$} & \multicolumn{2}{|c|}{$\begin{array}{c}\text { Aflatoxins } \\
n g / g^{b}\end{array}$} \\
\hline & & & Immunoaffinity & TLC \\
\hline 1 & 12.2 & 2 & 660 & 531 \\
\hline 2 & 12.7 & 3 & 140 & 35 \\
\hline 3 & 12.5 & BS & 1,600 & 96 \\
\hline 4 & 12.1 & BS & 3,000 & 276 \\
\hline 5 & 14.3 & 3 & 32 & 13 \\
\hline 6 & 20.7 & 1 & 180 & 380 \\
\hline 7 & 20.1 & 2 & 57 & 644 \\
\hline 8 & 20.6 & 3 & 210 & 350 \\
\hline 9 & 21.0 & 3 & 26 & 253 \\
\hline 10 & 13.5 & BS & 94 & 45 \\
\hline 11 & 12.8 & 3 & 270 & 12 \\
\hline 12 & 13.5 & 3 & 13 & 29 \\
\hline 13 & 25.0 & 2 & 100 & 1,212 \\
\hline 14 & 13.7 & 2 & 1,800 & 1,822 \\
\hline 15 & 13.5 & 2 & 480 & 1,902 \\
\hline 16 & 14.8 & 1 & 8 & 146 \\
\hline 17 & 12.3 & 3 & 3 & 63 \\
\hline 18 & 13.2 & BS & 830 & 311 \\
\hline 19 & 12.8 & BS & 8 & 66 \\
\hline 20 & 16.1 & 3 & $0^{c}$ & 0 \\
\hline 21 & 24.7 & 2 & 0 & 6 \\
\hline 22 & 19.5 & BS & 0 & 0 \\
\hline
\end{tabular}

a - Qualitative Types 1, 2, 3 or BS (Below Standard) for the samples according to the percentage of the grain groups present in the lot (Brazilian grading Port. $n^{\circ} 845,1976$ ). percentage of the grain groups present in the lot (Brazilian grading Port. $\mathrm{n}$ - 845 , 1976).
immunoaffinity method in the industry and total contamination estimated by Thin Layer Chromatography (TLC) of grain groups belonging to the samples. c - Contamination value of zero means that contamination was not detected above detection methodology limit (0.1ng/g for immunoaffinity column and $\mathrm{lng} / \mathrm{g}$ for the TLC).

The correlation between fraction levels in the sample and total aflatoxin contamination levels estimated (table 2) or determined by immunoaffinity method (Table 1), was not statistically significant $(\mathrm{P}<0.05)$. Hence, for samples considered in this study, there is no relationship between aflatoxin contamination level and fraction levels in the sample. Among the samples with contamination level above legal limit of 20ng/g [3], it was observed that samples with a poorer grading type (type 3 and BS - below standard) were no more frequent than those that had a better grading type (type 2). The results in Table 1 showed that 17 samples had contamination above the legal limit (by TLC results) and among those the number of samples with qualitative types 2, 3, and Below Standard (BS) were the same, 5 for each one. Only two samples were graded as type 1 , the best qualitative type by Brazilian grading rules. Nevertheless, these two samples had aflatoxin contamination (level of 146 and 380ng/g by TLC method) showing that sometimes apparently good quality maize, i.e., those with the best qualitative characteristics, can 
TABLE 2. Weight and aflatoxin contamination $(\mathrm{B} 1+\mathrm{B} 2+\mathrm{G} 1+\mathrm{G} 2)$ of fractions separated from maize samples.

\begin{tabular}{|c|c|c|c|c|c|c|c|c|}
\hline \multirow{2}{*}{ Sample } & \multicolumn{2}{|c|}{ Fraction $1^{\mathrm{a}}$} & \multicolumn{2}{|c|}{ Fraction $2^{\mathrm{a}}$} & \multicolumn{2}{|c|}{ Fraction $3^{\mathrm{a}}$} & \multicolumn{2}{|c|}{ Fraction $4^{\mathrm{a}}$} \\
\hline & $\begin{array}{l}\text { Weight } \\
g(\%)^{b}\end{array}$ & $\begin{array}{l}\text { Contam. }^{\mathrm{C}} \\
\mathrm{ng} / \mathrm{g}(\%)^{\mathrm{d}}\end{array}$ & $\begin{array}{c}\text { Weight } \\
\mathrm{g}(\%)\end{array}$ & $\begin{array}{l}\text { Contam. } \\
\text { ng/g (\%) }\end{array}$ & $\begin{array}{c}\text { Weight } \\
\text { g (\%) }\end{array}$ & $\begin{array}{l}\text { Contam. } \\
\text { ng/g (\%) }\end{array}$ & $\begin{array}{c}\text { Weight } \\
\text { g (\%) }\end{array}$ & $\begin{array}{l}\text { Contam. } \\
\text { ng/g (\%) }\end{array}$ \\
\hline 1 & $202(6.2)$ & $1,581(18.6)$ & $977(30.2)$ & $1,117(63.6)$ & $2,005(62.0)$ & $137(16.0)$ & $51(1.6)$ & 609 (18) \\
\hline 2 & $86(2.3)$ & 611 (39.9) & 625 (16.7) & 115 (54.6) & 2,896 (77.5) & $2(4.4)$ & $132(3.5)$ & $11(1.1)$ \\
\hline 3 & $96(2.2)$ & 728 (16.8) & $634(14.6)$ & $395(60.1)$ & $3,431(79.3)$ & $12(9.9)$ & $167(3.9)$ & 330 (13.2) \\
\hline 4 & $104(4.3)$ & $3,272(51.4)$ & 407 (17.0) & 219 (13.5) & $1,747(72.8)$ & 115 (30.3) & $143(6.0)$ & $226(4.8)$ \\
\hline 5 & $129(3.4)$ & $38(9.5)$ & $1,063(27.6)$ & 35 (72.5) & 2,575 (67.0) & $3(15.0)$ & $79(2.1)$ & $19(2.9)$ \\
\hline 6 & $108(3.1)$ & $3,428(28.4)$ & 375 (10.9) & $888(25.6)$ & 2,904 (84.6) & 205 (45.7) & $44(1.3)$ & $89(0.3)$ \\
\hline 7 & 87 (2.3) & 1,106 (3.9) & $442(11.6)$ & $2,754(49.8)$ & $3,211(84.6)$ & $351(46.1)$ & $55(1.4)$ & $71(0.2)$ \\
\hline 8 & $54(1.6)$ & $1,356(6.3)$ & 366 (11.1) & 937 (29.7) & 2,805 (85.2) & 240 (58.3) & $69(2.1)$ & $937(5.6)$ \\
\hline 9 & $54(1.4)$ & $1,036(5.8)$ & 39 (10.3) & 925 (37.4) & 3,291 (86.5) & $162(55.3)$ & $69(1.8)$ & 207 (1.5) \\
\hline 10 & 109 (3.5) & $129(9.9)$ & $438(14.0)$ & $159(49.2)$ & 2,475 (78.9) & $22(38.4)$ & $116(3.7)$ & $30(2.5)$ \\
\hline 11 & $57(1.3)$ & 220 (24.5) & $302(7.1)$ & $75(44.2)$ & 3,767 (88.0) & $0(0)$ & $154(3.6)$ & 104 (31.3) \\
\hline 12 & $119(4.0)$ & $61(8.4)$ & 487 (16.5) & $12(6.7)$ & $2,200(74.7)$ & $9(22.9)$ & $141(4.8)$ & 381 (62.0) \\
\hline 13 & $151(5.0)$ & $5,283(22.0)$ & 418 (13.9) & $1,404(16.2)$ & 2,381 (79.4) & $929(60.8)$ & $47(1.6)$ & $750(1.0)$ \\
\hline 14 & $264(6.4)$ & $6,671(23.3)$ & 577 (13.9) & 7,203 (54.9) & 3,259 (78.4) & 485 (20.9) & $55(1.3)$ & $1,281(0.9)$ \\
\hline 15 & $231(5.6)$ & $5,345(15.8)$ & 517 (12.6) & 9,489 (62.8) & 3,308 (80.6) & 478 (20.3) & $48(1.2)$ & $1,754(1.1)$ \\
\hline 16 & $109(2.7)$ & $2,106(38.1)$ & $382(9.4)$ & $688(43.6)$ & $3,502(86.1)$ & 28 (16.3) & 75 (1.8) & $159(2.0)$ \\
\hline 17 & $192(4.9)$ & 740 (57.3) & $613(15.6)$ & $132(32.6)$ & 3,045 (77.3) & $4(4.9)$ & 88 (2.2) & $145(5.2)$ \\
\hline 18 & $153(4.1)$ & $5,643(74.2)$ & $562(15.0)$ & 405 (19.6) & 2,752 (73.5) & $24(5.7)$ & $276(7.4)$ & $25(0.5)$ \\
\hline 19 & $92(3.0)$ & $22(1.0)$ & $398(13.1)$ & 432 (85.9) & 2,335 (77.0) & $3(3.5)$ & $208(6.9)$ & $92(9.6)$ \\
\hline 20 & $28(0.6)$ & 7 (100.0) & 655 (15.0) & $0(0)$ & 3,537 (81.2) & $0(0)$ & $138(3.2)$ & $0(0)$ \\
\hline 21 & 49 (1.4) & $0^{e}(0)$ & 59 (16.3) & $32(83.5)$ & 2,896 (80.2) & $1(12.8)$ & $76(2.1)$ & $11(3.7)$ \\
\hline 22 & $89(1.8)$ & $0(0)$ & $58(11.5)$ & $0(0)$ & 4,246 (84.2) & $0(0)$ & $126(2.5)$ & $0(0)$ \\
\hline
\end{tabular}

a - Fraction 1 - fermented, sprouted, moldy, and heated grains. Fraction 2 - Damaged grains (insect damaged, hollow, up to $1 / 4$ fermented and damaged by other causes). Fraction 3 - regular grain. Fraction 4 - impurities, foreign materials and other fragments); $b$ - Contam. - means contamination; $\mathrm{c}-$ Percentage contribution in the total weight
of the whole sample; $d$ - Percentage contribution of the fraction in the estimated contamination for the whole sample. $\mathrm{e}-0$ means that contamination was not detected above lng/g.

be highly contaminated with aflatoxin. Hence, the presence or absence of particular maize fraction, as considered by the Brazilian grading rules, does not eliminate the possibility that maize may have high aflatoxin levels.

Similar results showing no association between maize appearance with the presence of mycotoxins were reported by WILLIANS et al. [15], who studied the presence of mycotoxins in whole and damaged grains (color altered grains). These researchers did not detect the presence of ochratoxin A (minimum level of detection lng/g), sterigmatocystin (2ng/g), moniliformin (1,000ng/ g), zearalenone (10ng/g), acetil-deoxynivalenol (100ng), nivalenol (500ng/g), T-2 toxin (100ng/g), and diacetoxyscirpenol (500ng/g) in any fraction. Only aflatoxin contamination was detected and the contamination was present in two samples: one was in the whole grain fraction $(8 \mathrm{ng} / \mathrm{g})$ and the other in the damaged grain fraction $(6 \mathrm{ng} / \mathrm{g})$. For the most part, the non-whole grain fractions (with any alterations in the appearance) revealed that there were no detectable levels of aflatoxin or other mycotoxins.

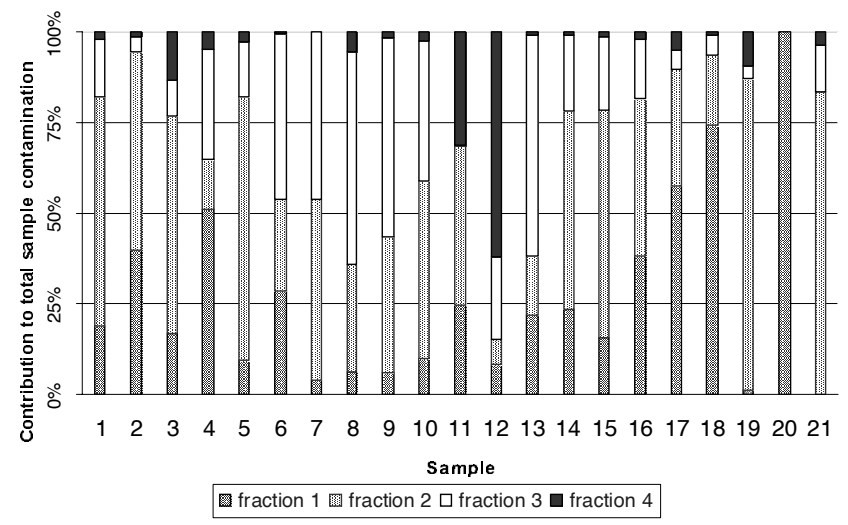

FIGURE 1. Contribution of fractions to total contamination in each sample. 
TABLE 3. Percentile analysis of fraction contributions to the total sample aflatoxin contamination

\begin{tabular}{lccccc}
\hline Statistics & Fraction 1 & Fraction 2 & Fraction 3 & Fraction 4 \\
\hline First Quartile (Q1) & $6.9^{\mathrm{a}}$ & 21.1 & 5.1 & 1.0 \\
Median & 17.7 & 43.9 & 16.1 & 2.2 \\
Third Quartile (Q3) & 35.7 & 58.8 & 36.4 & 5.5 \\
$\begin{array}{l}\text { Interquartile range } \\
\quad \text { (Q3 - Q1) }\end{array}$ & 28.8 & 37.8 & 31.3 & 4.5 \\
\hline
\end{tabular}

a-Percentage data of fraction contribution related o the total sample contamination.

\section{4 - CONCLUSIONS}

The maize fractions comprising fermented, sprouted, moldy, and heated grains showed, in general, higher levels of aflatoxin contamination than other separated fractions. Fraction 2 was frequently the major contributor to the level of sample contamination. However, as the fraction contributions varied from sample to sample, it was not possible to establish if one specific fraction was the major contributing factor responsible for the final aflatoxin contamination in different maize lots.

There was no statistically significant correlation $(\mathrm{P}<0.05)$ in the studied samples between fraction levels and total aflatoxin contamination levels. The qualitative maize types such as those considered in the Brazilian maize grading showed no correlation with aflatoxin contamination levels.

\section{5 - REFERENCES}

[1] AOAC. 1995. Official Methods of Analysis of the Association of Official Analytical Chemists, 16th ed. Method 971.22; 985.17. The Association: Arlington, Washington.

[2] BRASIL - Diário Oficial da União. Portaria MAARA No. 845 of November $8^{\text {th }}$, 1976 , published on November $19^{\text {th }}, 1976$.

[3] BRASIL - Diário Oficial da União. Portaria SFA No. 183 of March 21st, 1996 published on March 25th, 1996.

[4] FONSECA, H.; NOGUEIRA, J.N.; GRANER, M.; OLIVEIRA, A.J.; CARUSO, J.G.B.; BORALLI, C.; CALORI, M.A.; KHATOUNIAN, C.A., 1982, Natural occurrence of mycotoxins in some Brazilian foods. $5^{\text {th }}$ International Iupac Symposium on Mycotoxin and Phycotoxins, Vienna, 1982. Proceedings (Vienna). pp.76-79.

[5] FONSECA, H.; NOGUEIRA, J.N.; GRANER, M.; OLIVEIRA, A.J.; CARUSO, J.G.B.; BORALLI, C.; CALORI,
M.A.; KHATOUNIAN, C.A., 1983, Natural occurrence of mycotoxins in some Brazilian foods. Part II. $6^{\text {th }}$ World Congress of Food Science and Technology, Dublin, 1983. Proceedings (Dublin, Boole Press). pp. 53-54.

[6] GLORIA, E.M. Occurrence of mycotoxins in maize delivered to food industry in Brazil. Tropical Science, n. 37, p. 21-24, 1997.

[7] JOHNSON, R.M.; GREENAWAY, T. Sampling stored maize for aflatoxin assay. Cereal Science Today, n. 14, p. 25-29, 1969

[8] LEE, L.S.; LILLEHOJ, E.B.; KWOLEK, W.F. Aflatoxin distribution in individual maize kernels from intact ears. Ceral Chemistry, n. 57, p. 340-343, 1980.

[9] SABINO, M.; RODRIGUEZ-AMAYA, D. Mycotoxin research in Brazil. Ciência e Cultura (Journal of the Brazilian Association for the Advancement of Science), v. 45, p. 359-371, 1993.

[10] SHOTWEll, O.L.; GOULDen, M.L.; Hesseltine, C.W. Aflatoxin: distribution in contaminated maize. Cereal Chemistry, v. 51, p. 492-499, 1974.

[11] SHOTWELl, O.L.; GOULDEN, M.L.; HeSSELTINE, C.W. Aflatoxin contamination: association with foreign material and characteristic fluorescence in damaged maize kernels. Cereal Chemistry, v. 49, p. 458-65, 1972.

[12] SHOTWELL, O.L.; GOULDEN, ML.; LILLEHOJ, E.B.; KWOLEK, W.F.; HESSELTINE, C.W. Aflatoxin occurrence in 1973 maize at harvest. III Aflatoxin distribution in contaminated, insect-damage maize. Cereal Chemistry, v. 54, p. 620-626, 1977.

[13] SOARES, F.J.; FARIAS, A.A.; CESAR, C.C. Introdução à estatística. Rio de Janeiro, Guanabara Koogan, cap. 13, 1991, p. 247-262.

[14] SOARES, L.M.V.; RODRIGUEZ-AMAYA, D.B. Survey of aflatoxins, ochratoxin A, zearalenone and sterigmatocystin in some Brazilian food by using multitoxin thin-layer chromatographic method. Journal of the Association of Official. Analitycal Chemists, v. 72 , p. 22-26, 1989.

[15] WILLIANS, K.C.; BLANEY, B.J.; DODMAN, R.L.; PALMER, C.L. Assessment for animal feed of maize kernels naturally infected predominantly with Fusarium moniliforme and Diplodia maydis. I. Fungal isolations and changes in chemical composition. Australian Journal of the Agricultural Research, v. 43, p. 773-82, 1992.

\section{6 - ACKNOWLEDGEMENTS}

This work was supported by FAPESP (Fundação de Amparo à Pesquisa do Estado de São Paulo, Brazil) grant no. 98/11701-8. 